\title{
Phage Therapy in Aquaculture- Hopes and Challenges
}

\author{
Asher Wilf* \\ Rabin Science Park, Israel \\ Submission: February 15, 2017; Published: March 27, 2017 \\ *Corresponding author: Asher Wilf, 4, Pekeris St., Rabin Science Park, Rehovot 76702, Israel, Tel: +972-52-446782, 972-8-947-1837; Fax: +972 \\ 8-947-1845; Email: asher@phage-biotech.com
}

\section{Short Communication}

Phage Technology harbors great promise in the prevention and control of bacterial disease in Aquaculture generally, and in hatcheries in particular. The proliferation of recent applied research addressing bacterial control by phages supports this claim $[1,2]$.

Bacteriophages, in brief, are bacterial viruses which attack and lyse bacteria, while replicating in the process. Phage Therapy is a biological anti-bacterial technology which emerged in the 1930s following their discovery. Phages may be administered locally on bacterial infection sites or contact surfaces, and can eradicate bacterial concentrations in a matter of hours, reducing bacterial loads by several orders within minutes [3]. Phages are rapidly metabolized and eliminated by the thymus, liver and spleen via the reticulo endothelial system $[4,5]$.

With the introduction of stable and wide-range antibiotics in the early 1940s, the strain-specific Phage therapy was summarily abandoned in the West, but went on to thrive and prosper in the Soviet Union where it has become an established clinical practice in human therapeutics and prophylactics, to this day [6]. The renewed recognition of Phage Therapy in the West, following the collapse of the Iron Curtain and the exposure to the Soviet experience, has met with the growing interest in alternatives to chemical antibiotics, in view of the expanding and escalating antibiotic-resistance in humans and the phasing out of antibiotics in food production [2].

In hospitals and food processing facilities, sanitation is exacerbating the problem by disrupting the microbial environment and by generating selective pressures that favor specific pathogens [7]. Phage Therapy is re-emerging and is rapidly gaining recognition and acceptance in a range of fields; especially in Human and Animal Therapeutics, Agriculture and Food Safety [8-10]. In 2014, FDA-USDA designated the first phage product targeting Listeria in chilled foods, as GRAS. The first of its kind "Food Processing Aid".
Organic ingredient (OMRI) recognition followed http:// www.fda.gov/ucm/groups/fdagov-public/@fdagov foodsgen/ documents/document/ucm263921.pdf).Phage is increasingly recognized as the viable alternative to failing antibiotic treatments which have lost their therapeutic efficacy. These opportunities to use phages would benefit from further research and development, but are often met with obstacles from disinterested parties, such as chemical giants and "Big Pharma".

The following is a short list of potential reasons why this might be the case, as well as potential obstacles to furthering development of phage technologies:

A. The dominance of cleanliness and sanitation dogma in control of bacterial problems.

B. A universal reluctance to ingest viruses.

C. Concerns about phage resistance.

D. Concerns regarding temperate-lysogenic phages capacity to confer desired survival traits to bacteria, such as antibiotic resistance and pathogenicity.

E. Phage is not a stable molecule but rather a big and evolving microbe, which the industry is not set up to isolate, collect, select, cultivate and formulate, let alone monitor, refresh the phages composition, optimize and tailor.

F. Phages are not patentable.

G. Host-bacteria-phage pharmacodynamics and pharmacokinetics are complicated to model

H. Phages are too specific and varied as to justify full-scale clinical trials for any single phage formulation.

Still, there is a growing interest in applying phages in Aquaculture, which is undoubtedly related to the phasing out of antibiotics in fish, crustaceans and mollusk farming and for want of any other sustainable alternatives [11]. 
Applied research and early stage development have already demonstrated promising results in controlling bacterial infection in a variety of shellfish. A recent study looked to characterize and evaluate the efficacy of phages phT4A and ECA2 both independently and in a mixture to control e. coli, a common contaminant of bivalve molluscan shellfish. It found advantages both in eradication of bacterial colonies and prevention of bacterial immunity by way of mutation in the cocktail form of the admixture. Another study showed promise in the treatment of Vibrio species in prawn larvae. Given these successes, it is likely that Aeromonas and Streptococcal species in Sea Bass and Sea Bream and Rickettsia in Salmon could also be treated successfully with phages specific to these bacteria $[12,13]$.

While the concept is particularly attractive for hatcheries, due to the fact that high phage titer can be maintained in hatching and larval growing tanks, mixing liquid suspensions into grow-out ponds or sea cages is not currently a reasonable option. Another issue facing the phage industry concerns refrigeration, distribution, and storage of phages. A potential solution to this would be to present phages in dried form. This would be especially efficacious in their distribution to remote tropical or desert aqua farms. To this end, much research and development currently focuses on delivery in grow-out settings. Other potential solutions propose pre-treating live feed with phages, or advanced targeted and control-released phage feed adjuvants $[14,15]$.

Phages in Aquaculture are no longer a conceptual novelty, but represent instead a long awaited, indispensable and imminent imperative. None of the foreseen challenges present an insurmountable hurdle as to delay and forestall its acceptance as a bacterial control measure in Aquaculture.

\section{References}

1. Schmelcher M, Loessner MJ (2016) Bacteriophage endolysins: Applications for food safety. Curr Opin Biotechnol 37: 76-87.
2. Chanishvili N (2012) Phage therapy--history from twort and d'herelle through soviet experience to current approaches. Adv Virus Res 83: 3-40.

3. Vaks L, Benhar I (2011) In vivo characteristics of targeted drug-carrying filamentous bacteriophage nanomedicines. J Nanobiotechnology 9: 58.

4. Carlton RM (1999) Phage therapy: Past history and future prospects. Arch Immunol Ther Exp (Warsz) 47(5): 267-274.

5. Merril CR, Scholl D, Adhya SL (2003) The prospect for bacteriophage therapy in western medicine. Nat Rev Drug Discov 2(6): 489-497.

6. Rodriguez-Rubio L, Gutierrez D, Donovan DM, Martinez B, Rodriguez A, et al. (2016) Phage lytic proteins: Biotechnological applications beyond clinical antimicrobials. Crit Rev Biotechnol 36(3): 542-552.

7. Reardon S (2014) Antibiotic resistance sweeping developing world. Nature 509(7499): 141-142.

8. Nelson DC, Schmelcher M, Rodriguez-Rubio L, Klumpp J, Pritchard DG, et al. (2012) Endolysins as antimicrobials. Adv Virus Res 83: 299-365.

9. Schmelcher M, Donovan DM, Loessner MJ (2012) Bacteriophage endolysins as novel antimicrobials. Future Microbiol 7(10): 11471171.

10. Hagens S, Loessner MJ (2014) Phages of listeria offer novel tools for diagnostics and biocontrol. Front Microbiol 5: 159.

11. Ritterman JB (2006) Preventing antibiotic resistance: The next step. Perm J 10(3): 35-39.

12. Pereira C, Moreirinha C, Lewicka M, Almeida P, Clemente C, et al. (2017) Characterization and in vitro evaluation of new bacteriophages for the biocontrol of Escherichia coli. Virus Res 227: 171-182.

13. Crothers-Stomps C, Hoj L, Bourne DG, Hall MR, Owens L (2010) Isolation of lytic bacteriophage against vibrio harveyi. J Appl Microbiol 108(5): 1744-1750.

14. Cisek AA, Dabrowska I, Gregorczyk KP, Wyzewski Z (2017) Phage therapy in bacterial infections treatment: One hundred years after the discovery of bacteriophages. Curr Microbiol 74(2): 277-283.

15. Geier MR, Trigg ME, Merril CR (1973) Fate of bacteriophage lambda in non-immune germ-free mice. Nature 246(5430): 221-223.

\section{Your next submission with Juniper Publishers will reach you the below assets}

- Quality Editorial service

- Swift Peer Review

- Reprints availability

- E-prints Service

- Manuscript Podcast for convenient understanding

- Global attainment for your research

- Manuscript accessibility in different formats

( Pdf, E-pub, Full Text, Audio)

- Unceasing customer service

Track the below URL for one-step submission

https://juniperpublishers.com/online-submission.php 